\title{
Connecting Cultural Studies, Critical Theory and Critical Discourse Analysis: Past, Present, Future
}

\author{
Elfrida Kartika Dewi \\ Universitas Lancang Kuning \\ elfridakartikadewih@gmail.com
}

\begin{abstract}
In this journal the researcher have explored some of the inexorably connected histories, but also distinguishes, analyzes critical discourses and cultural studies . I argue that both are strongly influenced by the version of critical theory which has been characterized as 'postmodernism ' and 'poststructuralism ' and both can benefit not only from some serious engagements with some of the disciplines with which they are interdisciplinary, but also from some further in exploration depth of critical theory that informs them and that they are often 'translated ' or 'co-opted ' by reductionist means. I also argue that the claims that are sometimes made for critical discourse analysis are increased and without ethnography and serious attention to the theory and research on the context, such claims can not be sustained. On the other hand 'resignation ' or CDA cultural politics is an important agenda and we need to do more work to determine exactly how social change can be done through the kind of work CDA can do. My conclusion is that we need to reframe and contemplate the ways in which we define and do the CDA and it will involve the taking of cultural studies and critical discourse analysis together in a productive new way with other disciplinary and theoretical formations and with the attention that true to the new and different global and local contexts in which we work .
\end{abstract}

\section{INTRODUCTION}

Of the three main terms of the first half of my title, none is well defined, or understood in the same way, In different national, global, disciplinary or interdisciplinary contexts, each of which can be discursively or performatively produced and enacted . Cultural studies have been defined as an interdisciplinary effort 'relating to the analysis of cultural forms and activity in the context of power relations that conditions production , circulation, dissemination and, of course, their effects . ' (Bennett 1998:60). This definition, as broadly as possible, covers the whole range of disciplinary and interdisciplinary ventures : media and communication studies, some forms into semiotics, and works in many disciplines - eg Anthropology, Sociology, Education , Philosophy, History, Geography , Linguistics - influenced in the last twenty years of the 20th century , and is heavily criticized and rewritten, by the same form of critical theory and culture that forms the study of culture itself . It is this complexity that causes Angela McRobbie to speak of 'chaos in cultural studies ' (1992: 722 ). In all of these places certain pertinent theorists today are trivial, the social constructive view of language, Ideas and dexterity in the language and language they use in their everyday language relations are built and deconstructed through these processes, what we call social and culturally constructed and well-deconstructed this activity by narrative, Ie changing narratives, stories differently, can change the social world and the purpose of work and language is politics committed to social change through what Eco (1979) calls semiotics work on and with text .

Media studies, for example, If we allow the media to involve 'cultural forms and activities ' through which powers relations is formed, In current 'production, text, acceptance ' models, In accordance with Bennett's definition of Cultural Studies and in fact often part of what is 
done Cultural Studies (Durham / Kellner 2001 ). Media Studies Yet as we will see below often including content analysis and discourse as part of its repertoire, something less common to Cultural Studies .

Bennett 1993 ; Morley / Chen 1996 ; Curran / Morley / Walkerdine 1996 ; Storey 1996 ) is usually not done is a canonical literary text, because it has been historically compiled in English. Many places are in direct conflict with class-based elitism perceived in literary studies . Literature Studies (Valdes / Miller 1985 ; Rice / Waugh 1989 ) on the other hand, or English Studies in places where such terms remain unstructured by postcolonial theory, are also shaped and rewritten under the influence of critical theory, are actually now shared with culture . Learn the language understanding and theory I have summarized above . Cultural studies are also very lacking in history (Steedman 1992 ). It offers different types of engagements on critical theory (see below ), which at one time was almost as challenging on the study of literature as a study of culturing itself , and engaging in intermittent small battles with Critical Discourse Analysis : but 'discourse analysis ' in Cultural Studies derived from poststructuralist philosophy and theory .

Critical Theory is also often characterized both within and outside of Cultural Studies as 'poststructuralism ' or 'postmodernism ' and is increasingly seen to be loosely engaged with 'linguistic changes ' in human science (as described above) that have a strong impact in Cultural Studies and who is now , for those who characterize it so, fortunately it is almost behind us or something we should try to forget, or an ongoing problem (Norris 1992, 1993 , McRobbie 1994 ). On the other hand, the current form of Critical Discourse Analysis are almost entirely influenced by Critical Theory and is consequently largely rewritten as a company in the same period that the Culture of Study has become famous and institutionalized .

To be asked in this context to write about the relevance to Critical Discourse Analysis to Cultural Studies, therefore, ask for a lot of clarification on some of these issues and then some difficult decisions on the relevance, pragmatics, and the new context in which we teach and learn In my case , this also compelled me to recall the arguments I made in 1997 about linguistic issues and critical discourse analysis in relation to feminist theory (Threadgold 1997 ). Why do feminist theories never use linguistics, unless of course feminist theorists are linguists, and does the poststructuralist linguistic form has feminist theory ? Theoretically, many problems are similar to the issues raised now by this question related to cultural studies. Now, however, They need to rethink in the context of the nationstates ravaged by new technology and economic globalization, and at the local, community and classroom levels, reshaped by unlawful and dark currents, Information and capital, In a way that we hardly begin to theorize . Condo (1990), Wilson / Dirlik (1995), Lowe (1996), Gordon (1997 ), Baker Jr. Diawara / Lindeborg (1996 ), and Saldivar (1997) is one of the few texts that seriously addressed the problem We have become more or less adept in this context when re-imagining and homogenizing our students as a 'market ' to be interested in a quality assurance list that defines 'goals and outcomes ' promising secure economic benefits and a secure future. Questions about the relevance to Critical Discourse Analysis to the teaching of Cultural Studies are related to different pedagogical agendas, based on a vision for the future and a new narrative of what we should really build. From some of the complexities and confusions in which we now work, all of which have a history that also needs to be remembered . 
According to Hamuddin Budianto "The term "discourse" is a complex and mammoth-like interpretation. Many previous studies mention the term discourse as very ambiguous since its introduction to modern science and the various broad interpretations of discourse. Therefore, the definition of discourse reflected here will focus on the linguistics point of view, especially that of applied linguistics. Here, it refers to the speech patterns and how language, dialects, and acceptable statements are used in a particular community. Discourse as a subject of study looks at discourse among people who share the same speech conventions. Moreover, discourse refers to the linguistics of language use as a way of understanding interactions in a social context, specifically the analysis of occurring connected speech or written discourse, Dakowska (2001) in Hamuddin (2012)”.

\section{On 'Adding' CDA to Poststructuralist Cultural Studies.}

Barker / Galasinski (2001) discusses the separate cultural studies and discourse analysis (CDA ) in its current formate express CDA CDA . This is what this book says . "It is entitled 'A Dialogue on Language and Identity ', a focus I have a lot of sympathy, especially since it does not happen disagreement 'culturally or positioned as ' foreign law ' (2001 : 2223)" . Having recently was the first of all, from Australia to Wales, and when this is really a problem, I have found the book very valuable. It is said, I want to explore how to work , because CDA and Cultural Studies .

In this chapter was created as a review and a summary of what Saussure , Barthes , Derrida and Foucault (critical theory ) have contributed to the 'language philosophy ' currently informed in Cultural Studies. This is the 'position ' chapter and an introduction (2001: 2 ) . But theorists are critical to this one narrative . Raymond Williams compares with the structuralism of Hebdige (1979) about youth culture with the commitment to Paul Willis (1977: 1978 ) to ethnography (2001:6-7 ), and structuralist work seen by audience studies and consumption, and printing with the relationship between media and culture (2001: 7-8) . "This is a form of progress beyond structuralism and semiotics, and both of which engage in 'speech ' and 'speech texts ' (2001: 8 )", none of these works shows evidence of 'detailed language analysis ' .

The reading of 'poststructuralism and the Crisis of Representation ' (Clifford / Marcus 1986 ), which wrote it as a literary genre and conversation, but can not use structuralist semiotics tools because it is currently the subject of attack by Derrida and poststructuralism (2001 ) :9). The story of Derrida's critique and influence (p.21 ) is rejected as " high textualism " that rejects any ethnographic or empirical work '(2001:11). The influence of the derrida in the study of culture, feminism, postcolonial theory and Marxism is solid but not 'benign ' and the word 'politically practical use ' becomes a 'new language ' which can only be 'an elite intelligent ' (2001 : 11-12 ). First, Derrida always understands that deconstruction can not escape empiricism (Spivak $1988: 292$ ) and argues that the politics of deconstruction is about the inability, the hegemonic conceptual system for the outcome of social change . (1972/1982: 329$)$.

Let me quote Derrida here :

"I do not believe I have ever spoken of "indeterminacy" whether in regard to

"meaning" or anything else. Undecidability is something else again. ... I want to 
recall that undecidability is always a determinate oscillation between possibilities (for example, of meaning, but also of acts). These possibilities are highly determined in strictly concern situations (for example, discursive - syntactical or rhetorical - but also political, ethical etc.) They are pragmatically determined. The analyses that I have devoted to undecidability concern just these determinations and these definitions, not at all some vague "indeterminacy". I say "undecidability" rather than "indeterminacy" because I am interested more in relations of force, in everything that allows, precisely, determinations in given situations to be stabilised through a decision of writing (in the broad sense which I give to this word which also includes political action and experience in general. (1988: 148)."

This is because some people have understood Derrida's 'new language ' as about many things that CDA proponents propose as an essential part of a cultural politics and are ready to fight against language in order to disturb the instability of feminist discourse, postcolonial theorists, strange theorists and other radical groups have in fact found deconstruction to be of enormous political value . Identity politics developed in Barker / Galasinski can not be articulated without the 'new ' / difficult 'language ' given deconstruction. They also denied themselves to a cultural politics involving the writing of new stories with 'new language ' $(2001: 61)$. It is too easy to repeat a cliche about Derrida whose last writings on Algeria , globalization / peace , continue to argue that deconstruction has no political usefulness (2002) / if we, CDA supporters are not ready to struggle with 'new language ' when we find it, we should ask who is out there to be prepared?

In Barker / Galasinski , a record of Foucault follows Derrida's critique , with criticism that his work has been used more 'to inspire the study of discipline ' than 'power for ' (2001 : 14 ), that it does not, in other words, agency. Wittgenstein / Rorty was later introduced as an antidote to poststructuralism because in their work, certain types of pragmatism play a big role / show how 'endless means of pen ' is stabilized in actual practice / everyday life (2001 : 14-18 ). Ethnography rehabilitated for advanced use / CDA was introduced (rewritten as a good agreement with cultural studies previously described ). CDA is presented as a theory that offers 'the potential for systematic/ recurrent insights about linguistic forms capable of uncovering social practice ' (2001: 25 ). On the other hand cultural studies, without CDA, have 'been unable to show precisely how the construction of discursive cultural forms is achieved in everyday life ' (2001: 27 ). There is an element of this narration that I would like to cons and I will return to them below .

In language, identity and cultural politics, he reviews and introduces complex subject theory about Foucault and Lacan to Stuart Hall , Judith Butler , and Laclau. It includes the work of feminists in the body, questions about culture and biology and performability. But again there is an antidote given to the failures of poststructuralist theory that are considered important to give the agency theory or to explain how social change can take place : the psychology of personal intercourse, Wittgenstein, Rorty, and Giddens . This is a complex chapter that ends with a discussion of the cultural politics of language and identity (2001: 56 ). And the argument that these things are best learned 'not in philosophical arguments ', 'or as signs of the death of the text alone ' but by exploring ways in which 'claims of identity are attained in everyday linguistic meetings ' (2001:61 ). This chapter, like the former, relies heavily on poststructuralist work which attempts to be rewritten as a pragmatic for linguistic work. However, poststructuralist influences also radically change what 
CDA is like in this book, at least in terms of how the language tool for chapter three is framed . It becomes a CDA that is much more in tune with current issues in the study of contemporary culture and explicitly addresses the need for new theories about the new realities discussed above.

It is interesting that for Rorty, the author turned to the rewriting theory, which they called 're-description politics' :

"The language of cultural politics brings oppression 'into view' and expands the logical space for moral and political deliberation. This does not involve the discovery of truth, or less distorted perception in opposition to ideology, but the forging of a language with consequences which serve particular purposes and values as part of an evolutionary struggle which has no predetermined destiny. Cultural politics does not need essentialism or foundationalism but 'new languages' in which claims for justice do not sound crazy but come to be accepted as 'true' (2001: 57)"

The lesson of poststructuralism has been well studied here, contained in the list of what cultural politics do not, although Rorty's theories are being discussed. This is in turn criticized for failing to analyze the forces or using sociological analysis of 'institutions and organizations that produce and distribute cultural texts ' (2001: 58-59) . In relation to the latter, parallel to Bennett's (1998) critique of cultural studies to 'shift his politics to the level of meaning and text ' (2001:59) and fails to address the same problem. Western cultural political methods (1993) are then listed as : deconstruction, demythologation ('mapping the social construction of a metaphor that governs the description of the world') and demystification ('partisan analysis of the complexity of institutional structures and other forces ' to express the possibility for social change and to link theory new with communities and networks of real people ) (2001 : 58 ). This is the last study that according to Rorty and culture is lacking. I am commenting here only in passing that the theory of value rewriting is at least equivalent to this company can be developed from feminist, postcolonial and bizarre theories and new Marxism . Apart from the dominance of poststructuralist theory about, when we come to chapter 3 'Tools for Discourse Analysis ', and regardless of the self-reflexivity recognition that analysts demand, and the inclusion of intertextuality as a feature of the text, the CDA looks beautiful. Same as the standard summary (good ) of the language theory we already know above and the functional linguistics of Hallidayan . There is a nod to CDA as its own theory, but it is now claimed to provide a replicable , systematic and verifiable methodology . It goes back to the language of social science and social science research methods of interesting textbooks. I think there is a good reason why CDA can not really be all this and they should do , as Halliday suggests (Threadgold $1997: 104 \mathrm{ff}$. ), With the grammatical category incompetence and the difference between grammatical as a metallic language and actual Texture language of the language used. In this case it compares with most of the social science research methods and poststructuralist techniques with the latter distinction recognizing the difficulty in making such claims. While I will use the checklist of the same tools as the one used here, I also want to do it again (more below ). The difficulty inherent in making such claims is not clearer than the two case study chapters (Barker / Galasinski 2001 , chapters 4 and 5 ). Each is rich and detailed in its readings of masculinity and ethnicity as constructed in everyday linguistic performance, but both use the same tools for chapter 3 as an emulsive methodology. Both rely heavily on the experience and knowledge of the researchers, and in fact would be difficult to replicate correctly , although I would argue that the language theory we use with the assumption that 
language is a patterned and systematic phenomenon, that similar texts will occur in other contexts, and some types similar results would be possible if a similar question was also raised on the text. My points is that much of the interpretive work continues in such an analysis, whether at the level of determining the most important grammatical categories for this collection of texts, or mapping the text into context by looking at larger structures such as language and religion (Barker / Galasinski , ch . 5 ) .

For example, this analysis focuses on the agency structure of the narrative on ethnicity, decides to use transitivity, but makes a conscious decision to ignore the 'explicit error prejudice ' that supports 'the principle of responsibility in the language sense ' (2001 : 145 ). The decision could only come from the knowledge and experience of the researchers about this population and the text they analyzed : 'Misplaced guesses expected to be put by Poland in Ukraine ' (page 145) and very less desirable .

Structuralist analysis might call this the foreground option. That this is an interpretative and context-bound decision will be expected from an identification of the identity, subjectivity and habitus of the researchers, but instead makes them impossible to be fully imitated. And indeed if we look at another review of the work on ethnic markers by which this chapter begins we find that Wodak et . Al (1999) and Meinhof / Galasinski (2000) has made different types of interpretive choices of their analysis of ethnicity discourse and narrative in other contexts. None of this has to be surprising in terms of the language theory and identity that this book sets forth as the framework in the early chapter. I also do not see the inevitability of interpretative differences in doing CDA as a problem . Some of the richness of such an analysis exists in what can be seen and read from different perspectives . However, this distinction is not easily discussed with arguments about objective, systematic, replicable and verifiable social science methodologies . Questions about the performance of text / context contexts are also interesting . The researchers argue very convincingly for their analysis because it shows an anti-essential view of context-bound ethnicity and is related to life in a particular community $(2001: 129,135)$. However, the context is actually built by researchers as a fairly narrow (and textual ) historical record of the history associated with the second world war and its consequences : publications made by the council of society and historical debates in a local newspaper (2001: 128 ). On the other hand, knowledge of the way in which language and religion or work practice contribute to contradictory ethnic constructions in narratives largely reads the narrative itself , historically and projected into the context of society as evidence of the nature of the context that is bound to construction (eg, 2001: 135). That is , there is no apparent demystification in the sociological analysis of the West Institute (1993) on institutions and community practices independent of textual analysis . Interview texts are 'read ' with some CDA tools, but the entire reading does not look very different from the kind that might be done by sociologists or anthropologists without CDA ornaments .

There is no clear reference to intertextuality, or the ways in which interview data contribute to an understanding of the discourse, genre or narrative of ethnicity existing in this particular context, nor is the speaker's position in and by discourse, genre and narrative explicitly theorizing within its relation to the institutional, organizational and family contexts, and what Halliday calls social semiotics from material history, geography, language and religion, for example. Such a framing may involve different types of analysis and understanding of the production of hetero gloss and dialogical texts and 'multiple dual identities ' than those given here when the focus is on ethnic identity as 'the achievement of the topic ' (2001: 149). That is , attempts to debate the 
CDA against, or in addition, poststructuralist cultural studies seem to also fail at the deconstruction level, since he has seen binary subjects, disciplined subjects / agents , and selects almost entirely for agents, under-theorising ways in which speakers also uttered by the discursive, narrative and generic intertext that builds them as they establish their identity. In fact, in my opinion, the deconstruction will involve the usual supervisory agency about the placement of both and simultaneously. That is why as speakers we have unconscious control over generic structures but not beyond the interface fragments we create together to create text.

\section{Some Digressions on Intellectual Histories and Myths}

After researching in detail a study that is a product of the complexities I explore here , I want to go back to the cultural study narrative and capture some unbuilt binaries that still seem to haunt us. Once Cultural Studies has established themselves as separate from Literature Studies, it remains the subject of disciplinary disputes that have left their mark on their own cultural formations and activities . Despite his desire to distinguish himself from literary studies , many of his earliest supporters received their training in literature, and critical theory, which was also influential in literary studies, was dominant both in its formation and in its distinctive mode of analysis.

I will characterize what I mean by this 'critical theory ' as poststructuralist / postmodernist work of Bakhtin , Barthes , Kristeva , Freud, Lacan , Foucault and Derrida to name some and relate it to criticism of structuralism, enlightenment and empiricism . among others But I want to be very clear that a criticism or deconstruction of these things does not involve a rejection of them . Often it involves a complex understanding of the ways in which they are embedded in our way of thinking and being and can not be avoided. As a consequence of these criticisms, the modes of research and analysis of cultural studies remain textual and literary / philosophical in their derivation, and are largely based humanities. They involve various forms of critical reading practice, informed by the theory that drives them : for example , psychoanalytic or deconstructed readings . Ideologically, this inheritance coupled with criticism of structuralism and empiricism resulted in research positions that appear to contradict the articulation of explicit methodology, as part of a disciplined disciplinary purity and easily recognizable disciplinary location. However, this does not mean that there After examining in detail a study that is a product of the complexities I explore here , I want to go back to the cultural study narrative and capture some unbuilt binaries that still seem to haunt us. Once Cultural Studies has established themselves as separate from Literature Studies, it remains the subject of disciplinary disputes that have left their mark on their own cultural formations and activities . Despite his desire to distinguish himself from literary studies , many of his earliest supporters received their training in literature, and critical theory, which was also influential in literary studies, was dominant both in its formation and in its distinctive mode of analysis.

This does not mean that there is no methodology, nor is it possible to articulate it . Increasingly, to teach cultural studies in this fashion, and to satisfy publishers who want to produce sold textbooks, methodologies must be produced . Axelrod / Cooper (1993 ) . Reading Critically, Writing Well and Schirato / Yell (1996 and 2000 ) . Cultural Communication and Literacy is a case in the U.S. and Australia . Other contexts in which reading strategies (of the type of literary and cultural studies ) is done explicitly in course of educational studies and literacy where the deconstruction of current practices for political purposes and foresight for better teaching practices (in the 
sense of separation in for understanding ) are interventions which is common and important (Luke / Freebody / Gilbert 1993 ; Luke 1997 ). In a more theoretical fashion, Barbara Johnson in his introduction to Derrida's Disissination (1981) shows very effectively how it is likely in any Derrida texts, to explain his methodology and that the method is actually language-based and rhetorical, even when he uses linguistics and rhetoric to deconstruct his location where they are . And there are many accounts by those who are critical of the method of cultural study exactly how it works (eg , Hunter 1992 , Steedman 1992 ). The question about empiricism versus textual relates to methodological issues and also needs some demolition here . This binary opposition is very interesting and I will gradually try to deconstruct what follows . It appears in Barker / Galasinksi (2001 ) with consistently positive values "given to everyday life and speaks of writing or text, despite the fact that daily life is subsequently reduced to text for analytical purposes . It is clear that the complex interplay between discursive and material, between language and corporeal, between geography, institutions , bodies and text, is something that cultural studies must study, and that insufficient attention is given to non-different aspects of the collection this . What poststructuralist theory holds that the empirical / textual binaries must be deconstructed , that writing does not (mis-) represents speech as a pure and original form , that both speech and writing are writings in the complex sense Derrida gives the word with. Suddenly, the textual over-empirical privilege as part of criticism of the poststructural is the inversion that can not be done, not deconstruction , of the binary . McRobbie (1992 : 730 ) is correct that : "The site of identity formation in cultural studies remains implicitly in and through cultural commodities and texts rather than in and through cultural practices in everyday life ' and the work of Butler $(1990,1993)$ is a a prime example of why work on cultural practices is necessary but needs to be done in a way that understands and theorizes the complex , material, and textual complexes in which cultural practices are practiced and enforced, not only with special remarks. Why , for example, collect texts in society (by interview, focus etc . ). More 'empirical ' than collecting text in libraries, on the internet, from newspapers ? What is collected remains 'textual' . Once it becomes empirical 'evidence ' rather than text, we see again the privileging of speech over writing. This is one way the text goes into 'decision relationships ', what Smith calls a textually mediated social organization (Smith 1990 ) which, he says , 'sociology is very blind ', rarely attends 'documentary or textual process like' . (Smith $1990: 209$ ). There is a positive sign that this is no longer the case (Kitzinger 1998, Cameron 2001 ) but we must be vigilant, from a sociological perspective, referring to the complexity of Derridean deconstruction, or Foucauldian derived from 'discourse analysis ' , for example, as only textual ', just because they start their work with text (often written ).

If we return to the constitution of cultural studies, this is precisely the empiricism / binarism of the text that marks the coming of Sociology and Anthropology, a discipline that has hitherto seen 'culture' and 'social' as their territory, in this newly formed interdisciplinary room. This is where the problem to be done with the practical effect in the study of culture on the so-called 'linguistic turn' of critical theory, the claim that 'everything is discourse', was first raised as an issue: and while, as I have suggested above, I does not believe that this is the only way to change 'linguistics' to read, surely this is the case in the popularization and enforcement of its theoretical position in textbooks and classes, and in summarizing such histories in Barker / Galasinski (2001), the complexity of the original theory (see Threadgold 1997, 2000) is lost due to a series of concepts that have lost their original strength and complexity and resulted in very less research in history and context (Steedman 1992; McRobbie 1992). Thus terms such 
as: signs, codes, representations, narratives, genres, intertextuality, myths, metanarratives, deconstruction, traces, supplements, subjectivity, habitus, identity, race, sex, class, sexuality and so multiply as metal language but with very little sense from history that produced them or from previous historical moments where similar concepts and research have been circulated. My criticism here can be compared with Curran's (Curran / Morley / Walkerdine 1996) report on the 'forgot', institutionalized 'revisionism', which is involved in the narrative of media audiences.

Nor is there any attempt on teaching a recent cultural study to provide a knowledge of the context, and a methodology for researching them, which will make all textual text works bring it up. I am thinking about the work of contextualization that can be done in courses of critical theory, political science, history, economics , geography , sociology and so on . In this 'interdisciplinary ' disorder, it is this disciplinary context that criticizes anti-method attitudes to be taken seriously . Cultural studies have rejected on the basis of this quantitative study (eg content analysis ), survey methods and questionnaires that support what Lewis calls 'microscopic, semiotic or literary treasures of special media texts ' or qualitative (but not textual ) analysis of the reception of media audiences and other texts (Williams 1999). McRobbie (1992) suggests the absence of sociology at Grossberg et . Al (1992) the anthology of cultural studies, in many ways the decisive text, and the failure of thinking, post-Marxism , which such a discipline has entered for poststructuralist and postcolonial and feminist critique, of transformative social politics . In 2003 , ten years later, it seems to me that the task is even more urgent because multicultural societies and globalization force us to ask many very difficult questions about the meaning of 'critical ' and for whom, who can speak for whom and about how do we re-theorize the textual and material networks that are constantly changing where we work .

A very binary alternative to the cultural language of cultural studies is to emphasize the reality of the material world and the need to study it, empirically, provide a type of identifiable evidence, using widely acceptable research methods of codified social science . and replicated. Media Studies, residing in and outside of Cultural Studies, such as Linguistics, in UK institutional form at graduate level, have largely adopted social science rather than humanities. This may not have anything to do with current ESRC funding arrangements and support for particular types of research method courses of postgraduate contexts (4)in UK universities . But that is also quite a lot to do with generating a lack of convincing theoretical media theory about the field. The fragmentation of the research methodology generated in the course of research methods, again without context, is now a detailed knowledge of the discipline of which method is used, aggravated at the degree level at which Williams showed some time ago , the textual influence of cultural studies / paradigms of deconstruction and parallel focus on subjectivity makes students without research tools that can help build a verifiable and representative world picture (Williams 1999:277) . The work of Glasgow Media Group provides an exception to the claim that we have no convincing media theory (Eldridge (ed . ) 1993 ; Miller et al . 1998 ; Philo (ed . ) 1999 ), bringing together both types of approaches . - A method of social science and a sophisticated understanding of language, texts and discourses on an interesting and productive way. But the complexities involved in books such as Mass Communication Circuits (1998) are not easily accessible to students when research methods are taught separately from the disciplines, without critical theory to explain or challenge their relationships and implications, and without some basic understanding of the textual role in the use method itself . 
The work of the Glasgow media group deconstructs the binary distinction between the social and human sciences I have built upon because it does work in a number of other areas in cultural studies and as we shall see in the analysis of critical discourse itself . Production studies in television and theater (performance studies, such as media studies and communication studies, overlap with cultural studies ), and audience studies in cultural studies and media studies seem to always be somewhat diminished in both traditions (Tulloch / Moran 1986 ; Ang 1996 ; Threadgold 1997 ; Tulloch 2000 ; Tulloch 1999 ) : But there is an uncomfortable truce here that continues in connection with Critical Discourse Analysis and to some extent explains why it is not covered in the dominant forms of Cultural Studies . Still , for critical theorists, a slightly suspicious form of empirical social science methodology in a field that includes feminism , strange theories, postcolonial theory and is still strongly influenced by the interdisciplinary attitude of interdisciplinary science methods, and often , to social scientists, who are also closely related with the issue of 'linguistic turns ' in cultural studies being the right choice.

\section{Conclusion}

In a sense, we return to the argument about Barker / Galasinski (2001 ) that we need empirical work to test the metaphors and narratives of critical theory . But we not only need to rethink talk as text and not proof. We also need to consider it appropriate, in space / time, in relation to institutional and community practice and knowledge, dialogue with other textual practices, mediate power relations and legal relations, calling for ethnography and CDA and may need to be analyzed both quantitatively and qualitatively. The work of Luke (1992 ) and Kamler et al (1994) is an example of Bourdieu's idea of "habitus : 'When political mythology is realized, transformed into permanent disposition, the way of standing, talking, walking well and thus feelings and thoughts ' can use in conjunction with Foucault and critical linguistic / discourse analysis to explore in the ethnographic sett of issues related to Butler. They use this tool to carefully observe and analyze the process (linguistic, physical, spatial, visual, etc . ) in which the body of a girl and boy becomes gender in the early class. The critical factor here is that the repetition of gender norms can be determined and analyzed and the means of intervention can therefore be planned to make changes. We do not have to rely on the weirdness of iterations or texts wandering themselves looking for signatures .

The CDA version (and I define this here by van Dijk doing above as a set of creative potential to work with, not a fixed method ) in such a context allows to see what happens to the level of detail that the poststructural category can not be achieved because of the extent abstractions where they work. CDA is also fully compatible with ethnographic work in place where habitus is formed . Detailed work and with linguistic and textual structures really produce agents for researchers . Understanding the detailed detailed ways in which the body is created and learning to do can clarify the site for intervention and even begin to predict the impact on political action . Of course Derridean criticism also applies : unexpected and unpredictable may occur, but the details provide another alternative to new types of action . 
In addition, linguistic works in the poststructuralist category, of the kind we have discussed above certainly shows the effect of iteration, but makes them also subject to political intervention and action. If for example, the intertextual category is always used 'intact ', not falsified, because it tends to be of a particular kind of analysis - 'this is racial discourse ', 'there is a genre embedded in other genres ' - they can only be explained and identified Analyze in detail, how they work, think about how they are institutionally supported and produced and what effects they have on the body, on organizing space and social interactions, for example, and you start to have some tools for intervening . at the most unintentional level of text . Herein lies the most difficult discourse to solve .

You also begin to understand the narratives, discourses and myths that form the habitus . Actually iterativitas and quotations, as defined by Derrida and Butler, seem to provide some of the best arguments about using this form of critical discourse analysis in the work of cultural studies .

However, in my opinion, the best work will continue to bring new theories and new long readings along with the work of critical linguistics . Only when such work continues to be informed and challenged by the difficult theory that this theory will continue to be creative and productive . 


\section{REFERENCES}

Althusser, Louis (1977): Lenin and Philosophy and other Essays. Surrey.

Ang, Ien (1996): LivingRoom Wars: Rethinking Media Audiences for a Postmodern World.

London.

Austin, John L. (1976): How to do Things with Words. Edited by Jo Urmson and Marina Sbisà. London/Oxford/New York.

Axelrod, Rise B./Cooper, Charles R. (1993): Reading critically, Writing Well: A Reader and Guide. Third edition. New York.

Bakhtin, Mikhail (1981): The Dialogic imagination: Four Essays by M.M. Bakhtin. Edited by Michael Holquist. Austin.

Bakhtin, Mikhail. (1986): Speech Genres and Other Late Essays. Edited by Cary Emerson and Michael Holquist. Austin.

Baker, Houston A. Jr./Diawara, Manthia/Lindeborg, Ruth H. (eds.) (1996): Black British

Cultural Studies: A Reader. Chicago/London.

Barker, Chris/Galasinski, Dariusz (2001) Cultural Studies and Discourse Analysis: A Dialogue on Language and Identity. London.

Barthes, Roland (1953/1967): Writing Degree Zero. New York.

Barthes, Roland (1964/1967): Elements of Semiology. New York.

Barthes, Roland (1986): "To Write: An Intransitive Verb?". In: Barthes, Roland (1986): The Rustle of Language. Oxford: 11-21.

Bennett, David (ed.) (1993): Cultural Studies: Pluralism and Theory. Dept. of English, University of Melbourne, Victoria.

Bennett, Tony (1998): Culture: A Reformer's Science. Sydney. 
Benveniste, Emile (1966): Problemes de Linguistique Generale. Paris.

Birch, David/O'Toole, Michael (eds.) (1988): Functions of Style. London.

Bourdieu, Pierre (1990): The Logic of Practice. Cambridge.

Butler, Judith (1990): Gender Trouble: Feminism and the Subversion of Identity. New York/ London.

Butler, Judith (1993): Bodies that Matter: On the Discursive Limits of "Sex". New York/London.

Cameron, Deborah (2001): Working with Spoken Discourse. London.

Clifford, James/Marcus, George (eds.) (1986): Writing Culture. Berkeley.

Curran, James (1996): "The New Revisionism in Mass Communication Research: A

Reappraisal". In: Curran, James/Morley, David/Walkerdine, Valerie (eds.): Cultural

Studies and Communications. London: 251-278.

Curran, James/Morley, David/Walkerdine, Valerie (eds.) (1996): Cultural Studies and Communications. London.

Deleuze, Gilles (1986/1988): Foucault. Translated and edited by Sean Hand. Minneapolis.

Derrida, Jacques (1967/77): Of Grammatology. Baltimore/London.

Derrida, Jacques (1972/1982): "Signature, Event. Context". Translated by Alan Bass. In:

Derrida, Jacques: Margins of Philosophy. Chicago: 307-330.

Derrida, Jacques (1978/1981): "Structure, Sign and Play in the Discourse of the Human

Sciences". Translated by Alan Bass. In: Derrida, Jacques: Writing and Difference. 
London/Henley: 278-294.

Derrida, Jacques (1988): Limited Inc. Evanston, III.

Derrida, Jacques (2002): Negotiations: Interventions and interviews 1971-2001. Stanford/ California.

van Dijk, Teun (2001a): "Multidisciplinary CDA: a plea for diversity". In: Wodak, Ruth/

Meyer, Michael (eds.): Methods of Critical Discourse Analysis. London: 95-120.

van Dijk, Teun (2001b): "Principles of Critical Discourse Analysis". In: Wetherell, Margaret

et. al. (eds.): Discourse theory and Practice: A Reader. London: 300-317.

Durram, Meenakshi/Kellner, Ddouglas M. (eds.) (2001): Media and Cultural Studies:

Keyworks. Oxford.

Eco, Umberto (1979): A Theory of Semiotics. Bloomington.

Eldridge, John (ed.) (1993): Getting the Message: News, Truth and Power. London.

Fairclough, Norman (1989): Language and Power. Essex, UK.

Fairclough, Norman (1992): "Discourse and Text: Linguistic and Intertextual Analysis within

Discourse Analysis". Discourse and Society, Vol. 3, No. 2.: 193-217.

Fairclough, Norman (1995a): Critical Discourse Analysis. London/New York.

Fairclough, Norman (1995b): Media Discourse. London.

Foucault, Michel (1975/1982): Discipline and Punish: The Birth of the Prison. Harmondswoth.

Foucault, Michel (1966/1973): The Order of things: An Archaeology of the Human Sciences. 
New York.

Foucault, Michel (1969/1972): The Archaeology of Knowledge. London.

Fowler, Roger (1981): Literature as Social Discourse: The Practice of linguistic Criticism.

Bloomington.

Fowler, Roger/Hodge, Robert/Kress, Gunther/Trew, Tony (1979): Language and Control.

London.

Gordon, Avery F. (1997): Ghostly Matters: Haunting and the Sociological Imagination.

Minneapolis/London.

Gray, Anne/McGuigan, Jim (eds.) (1993): Studying Culture: An Introductory Reader.

London.

Grossberg, Larry/Nelson, Cary/Treichler, Paula (eds.) (1992): Cultural Studies. New York/London.

Hall, Stuart (1996): Critical Dialogues in Cultural Studies. edited by David Morley and Kuan-Hsing Chen. London.

Halliday, Michael/Hasan, Ruquaya (1976): Cohesion in English. London.

Halliday, Michael (1978): Language as Social Semiotic: The Social Interpretation of Language and Meaning. London.

Halliday, Michael (1985): An Introduction to Functional Grammar. London.

Hamuddin, Budianto, and Faridah Noor Mohd Noor. "A Closer Look on Politeness Strategies in Malaysian Economic Journal." 2nd INTERNATIONAL SEMINAR ON LINGUISTICS. 2015. 
Hebdige, Dick (1979): Subculture: The Meaning of Style. London/New York.

Hodge, Robert/Kress, Gunther (1979/1993): Language as Ideology. Second edition. London.

Hunter, Ian (1988): Culture and Government: The Emergence of Literary Education. London.

Hunter, Ian (1992): "Aesthetics and Cultural Studies". In: Grossberg et. al. (eds.): Cultural

Studies. New York/London: 347-372.

Johnson, Barbara (1981): J. Derrida Dissemination. Chicago.

Kamler, Barbara/Maclean, Rod/Reid, Jo-Anne/Simpson, Allan (1994): Shaping up Nicely: the formation of schoolgirls and schoolboys in the first month of school. A Report to the Gender Equity and Curriculum Reform Project, Department of Education, Employment and Training. Canberra/Geelong/Victoria.

Kirby, Vicki (1997): Telling Flesh: The Substance of the Corporeal. London/New York.

Kondo, Dorinne K. (1990): Crafting Selves. Chicago.

Kress, Gunther/van Leeuwen, Theo (1996): Reading Images: The Grammar of Visual Design. London.

Kress, Gunther/van Leeuwen, Theo (2001): Multimodal Discourse: The Modes and Media of Contemporary Communication. London.

Kress, Gunther/Threadgold, Terry (1988): "Towards a Social Theory of Genre". Southern Review, 21: 215-243.

Kristeva, Julia (1970): Le Texte du Roman. The Hague/Paris/New York.

Kristeva, Julia (1974/1984): Revolution in Poetic Language. New York.

Lacan, Jacques (1966/1982): Ecrits: A Selection. Translated by Alan Sheridan. Bristol. 
Lee, Alison/Poynton, Cate (eds.) 2000: Culture and Text: discourse and methodology in social research and cultural studies. Sydney.

Lowe, Lisa (1996): Immigrant Acts: On Asian American Cultural Politics. Durham/London.

Luke, Allen (1992): "The Body Literate: Discourse and Inscription in Early Literacy

Training". Linguistics and Education 4: 107-129.

Luke, Allen (1997): "Shaping the Social Practices of reading". In: Muspratt, Sandy/Luke,

Allen/Freebody, Peter (eds.): Constructing Critical Literacies. Creskill/NJ: 185-225.

Luke, Allen/Freebody, Peter/Gilbert, Pam (1992): "What counts as reading in the secondary classroom: the selective tradition of reading practices and positions." In: Christie, Frances et al. (eds.): Teaching English Literacy. Vol. 2. Canberra: 113-124.

Luke, Carmen (1989): Pedagogy, Printing and Protestantism: The Discourse on Childhood. Albany.

Lyotard, Jean-Francois (1979/1984): The Postmodern Condition: A Report on Knowledge.

Manchester.

Meinhof, Ulrike H./Galasinski, Dariusz (2000): "Photography, memory and the construction of identities on the former East-West German Border". Discourse Studies, 2(3): 33233353.

McRobbie, Angela (1992): "Post-Marxism and Cultural Studies: A Postscript". In: Grossberg,

Lawrence et. al. (eds.): Cultural Studies. New York/London: 719-730.

McRobbie, Angela (1994): Postmodernism and Popular Culture. London. 
Miller, David/Kitzinger, Jenny/Williams, Kevin/Beharrell, Peter (1998): The Circuit of Mass Communication: Media Strategies, Representation, and Audience Reception in the AIDS Crisis. London.

Morris, Meaghan (1988): The Pirate's Fiancee: feminism reading Postmodernism. London.

Norris, Christopher (1992): Uncritical Theory: Postmodernism, Intellectuals and the Gulf War. Amherst.

Norris, Christopher (1993): The Truth About Postmodernism. Oxford.

Parker, Andrew/Sedgewick, Eve Kosofsky (1995): Performativity and Performance. London.

Pecheux, Michel (1982): Language, Semantics, Ideology. London.

Pheng, Cheah (1994): "Sexual Difference, Cultural Difference - Body and History in Gallop. In: Matthews, Julius (eds.): Jane Gallop Seminar Papers, Humanities research Centre, Monograph 7, Canberra: 47-71.

Philo, Greg (ed.) (1999): Message Received: Glasgow Media Group Research 1993-1998. London.

Poynton, Cate (1985): Language and Gender: Making the Difference. Oxford.

Poynton, Cate (1993): "Grammar, Language and the Social: poststructuralism and systemicfunctional linguistics". Social Semiotics 3, 1: 1-23.

Rice, Philip/Waugh, Patricia (eds.) (1989): Modern Literary Theory: A Reader. Third edition. London.

Rossi-Landi, Ferrucio (1973): Ideologies of Linguistic Relativity. In: Sebeok, T.A. (ed.): Approaches to Semiotics 4. The Hague. 
Saldivar, Jose David (1997): Border Matters: Remapping Cultural Studies. Berkley.

Sapir, Edward (1921): Language. New York.

de Saussure, Ferdinand (1959): Course in General Linguistics. Edited by Charles Bally and Albert Sechehaye. London.

Schechner, Robert (1985): Between Theatre and Anthropology. Philadelphia.

Schirato, Tony/Yell, Susan (1996): Communication and Cultural Literacy. Sydney.

Smith, Dorothy (1990): Texts, Facts and Femininity: Exploring the Relations of Ruling.

London.

Spivak, Gayatri (1988): "Can the Subaltern Speak?". In: Nelson, Cary/Grossberg, Lawrence (eds.): Marxism and the Interpretation of Culture. London: 271-316.

Steedman, Carolyn (1992): "Culture, Cultural Studies and the Historians". In: Grossberg,

Lawrence et. al. (eds.): Cultural Studies. New York/London: 613-621.

Storey, John (ed.) (1996): What is Cultural Studies? A Reader. London.

Thibault, Paul (1991): Social Semiotics as Praxis: text, social meaning making and Nabakov's Ada. Minneapolis.

Threadgold, Terry (1997): Feminist Poetics: Poeisis, Performance, Histories. London/NewYork.

Threadgold, Terry (2000): "Poststructuralism and Discourse Analysis". In: Lee, Alison/ Poynton, Cate (eds.): Culture and Text: 40-58.

Threadgold, Terry (2002): "Networks of Bodies and Texts: Accidents and/as Social Semiotics". Zeichenprocesse in Komplexen Systemen - Sign Processes in Complex Systems. Akten des 7. Internationalen Kongresses der International Association for Semiotic Studies (=Dresden Studies in Semiotics 4). 
Tulloch, John (2000): Watching Television Audiences: Cultural Theories and Methods.

London.

Tulloch, John/Moran, Albert (1986): A Country Practice: 'Quality Soap'. Sydney.

Tulloch, John/Lupton, Deborah. (1996): Television, Aids and Risk. Sydney.

Tulloch, John (1999): Performing Culture: Stories of expertise and the Everyday. London.

Turner, Victor (1987): The Anthropology of Performance. New York.

Valdes, Mario J./Miller, Owen (eds.) (1985): The Identity of the Literary Text. Toronto.

West, Cornel (1993): Keeping Faith. London/New York.

Wetherell, Margaret/Taylor, Stephanie/Yates, Simeon J. (2001): Discourse as Data: A Guide for Analysis. London.

Wetherell, Margaret (2001): "Debates in Discourse Research". In: Wetherell, Margaret. et. al. (eds.): Discourse Theory and Practice: A Reader: 380-399.

Whorf, Benjamin Lee (1956): Language, Thought and Reality: Selected Writings of Benjamin Lee Whorf. Edited by John B. Carroll. Cambridge/Massachusetts.

Williams, Kevin (1999): "Teaching Journalism in Britain". In: Philo, Greg (ed.): 271-281.

Willis, Paul (1977): Learning to Labour. Farnborough.

Willis, Paul (1978) : Profane Culture. London.

Wilson, Rob/Dirlik, Arif (eds.) (1995): Asia/Pacific as a Space of Cultural Production. Durham/London.

Wodak, Ruth/de Cilla, Rudolf/Reisigl, Martin/Liebhart, Karin (1999): The Discursive Construction of National Identity. Edinburgh. 
Wodak, Ruth/Meyer, Michael (eds.) (2001): Methods of Critical Discourse Analysis. London. Wodak, Ruth (2001): "What CDA is about - a summary of its history, important concepts and its developments". In: Wodak, Ruth/Meyer, Michael (eds): 1-13 